\title{
[Sem título]
}

\section{Victor Augustus Graciotto Silva}

Falar sobre a Revista Vernáculo significa relembrar uma das experiências mais marcantes que tive quando era estudante de História. É voltar ao ano de 1999, perambular novamente pelos corredores do sexto andar da Reitoria, voltar a sentar nas mesas do Roxinho, do Café Mafalda e do Karraspanas.

Era outubro, estávamos distribuindo um pequeno jornal, o Cesariana, formado de escritos (podemos dizer que eram literários) de minha autoria, do Rodrigo Turin e do Rafael Billy. Acabamos parando, como era de costume nos finais de tarde, no Roxinho, e lá, sentados na mesa, o inquieto Fernando me falou pela primeira vez da ideia de uma revista acadêmica de artigos científicos, feita por alunos do curso de História. Com artigos de pesquisas de graduandos, com um conselho editorial formado também por graduandos, que fosse distribuída entre os estudantes. Uma ideia simples, que somente precisava de um grupo de pessoas que a colocasse em prática. E esse grupo se formou. Em abril de 2000 o primeiro número da Vernáculo estava circulando pelas mãos de alunos e professores. Dez anos se passaram e ela continua existindo, seguindo as premissas que nortearam os primeiros anos da revista. E esse é um fato digno de nota. 
Esse norte da Vernáculo não foi dado, mas construído ao longo dos três primeiros anos da revista, com destaque para o ano de 2000, onde três números foram publicados. Nos editoriais destes números iniciais temos as reflexões sobre a identidade da Vernáculo, os seus propósitos e desafios. O que é necessário para se escrever um artigo? Desenvolver uma ideia? "Por acaso é necessário um diploma para que alguém possa, enfim, produzir algum saber? Por acaso é necessário colocar após o nome algum título de qualificação (mestrando, doutorando, professor, pesquisador, etc.) para que tal saber tenha validade?" Fernando, no editorial da primeira revista, diante da estranheza de alguns, que se perguntavam se era possível um aluno escrever um artigo científico e esse artigo ser publicado, mostra a pretensão da revista, despindo os autores de seus adornos e colocando os leitores a lerem e valorizem o saber por si. No segundo número, Allan escreve no editorial de forma clara a principal intenção da revista: "procura levar os graduandos a exercitarem o hábito de desenvolver suas ideias via texto [...] visa estimular o estudante a criar um senso de crítica em relação ao seu próprio trabalho e também de seus colegas, estabelecendo aí um espaço para o debate - fundamental no meio acadêmico". E tão importante quanto o exercício da escrita é o seu incentivo e valorização. E pego aqui emprestadas as palavras do Rafael, no editorial do terceiro número da revista: "Quando eles aceitaram meu trabalho e procuraram discuti-lo, eu entendi o porquê da existência da Vernáculo. Ela esta aqui para valorizar o trabalho de todos nós. Fomentar o exercício da escrita... é portanto um espaço de luta criado 
por alguns alunos para que todos eles possam fazer, através de seu agir, uma universidade mais ética."

$\mathrm{Na}$ revista de número cinco, no ano de 2002, a abertura que existia em relação aos colaboradores, já que tínhamos vários artigos e impressões de leitura feitos por alunos dos mais variados cursos, acontece também no conselho editorial. Diga-se de passagem que a revista sempre esteve aberta a todos os interessados em trabalhar nela. Contudo, foram poucos. E entenda-se: a revista ocupava um bom tempo nosso, seja lendo artigos, correndo atrás de patrocinadores, organizando os dossiês, diagramando, etc. Além da vontade, era preciso fazer ela acontecer. E aqueles que encararam esse desafio, falo por mim, mas acredito que seja um sentimento comum a maioria, sabem que participaram de algo bom. Algo que vale a pena ser contado. E saber que a revista está em plena atividade, completando dez anos e com o mesmo princípio - de graduando para graduando - me deixa feliz!

Atualmente estou trabalhando na área de edição de livros e de gestão cultural. E a experiência da Vernáculo foi o meu grande laboratório, mesmo sem eu ter essa consciência. Hoje, olho para aqueles anos e vejo como fomos bravos guerreiros, e daqueles tempos carrego uma virtude essencial: a coragem! 